\title{
Altered Excitatory and Inhibitory Amino Acid Receptor Binding in Hippocampus of Patients with Temporal Lobe Epilepsy
}

John W. McDonald, PhD, ${ }^{*}$ Elizabeth A. Garofalo, MD, ${ }^{*}$ Terry Hood, MD, $\dagger$ J. Chris Sackellares, MD,* Sid Gilman, MD, ${ }^{*}$ Paul E. McKeever, MD, PhD, Juan C. Troncoso, MD, and Michael V. Johnston, MD $\S^{* *}$

We examined binding to excitatory amino acid and inhibitory amino acid receptors in frozen hippocampal sections prepared from surgical specimens resected from 8 individuals with medically refractory temporal lobe epilepsy. The excitatory receptors studied included $N$-methyl-D-aspartate (NMDA), strychnine-insensitive glycine, phencyclidine, and quisqualate. The inhibitory receptors studied were gamma-aminobutyric acid type $A\left(G A B A_{A}\right)$ and benzodiazepine. Excitatory and inhibitory amino acid receptor binding were differentially altered in the patients with temporal lobe epilepsy in comparison to 8 age-comparable autopsy control subjects, and changes in receptor binding were regionally selective in four areas. Binding to phencyclidine receptors associated with the NMDA channel was reduced by 35 to $70 \%$ in all regions in the hippocampi of the patients. In contrast, binding to the NMDA recognition site and its associated glycine modulatory site was elevated by 20 to $110 \%$ in the cornu ammonis (CA) 1 area and dentate gyrus of the hippocampus of the patients. Binding to these sites was unaffected in area CA4. Binding to the quisqualate-type excitatory amino acid receptor was unchanged in all regions except the stratum lacunosum moleculare $\mathrm{CAl}$, where it was increased by $63 \%$. GABA $\mathrm{A}_{\mathrm{A}}$ and benzodiazepine receptor binding was reduced by 20 to $60 \%$ in CA1 and CA4, but unchanged in dentate gyrus. The data indicate that excitatory and inhibitory amino acid receptors are altered in the hippocampus of patients with temporal lobe epilepsy.

McDonald JW, Garofalo EA, Hood T, Sackellares JC, Gilman S, McKeever PE, Troncoso JC, Johnston MV. Altered excitatory and inhibitory amino acid receptor binding in hippocampus of patients with temporal lobe epilepsy. Ann Neurol 1991;29:529-541

Considerable evidence suggests that abnormalities of specific neurotransmitter systems play a role in epilepsy. Impairment of gamma-aminobutyric acid(GABA) ergic inhibitory neurotransmission may contribute to epilepsy: $G A B A$ type $A\left(G A B A_{A}\right)$ receptor antagonists are potent convulsants and GABAergic markers are selectively reduced in temporal lobe epilepsy (TLE) [1-8]. Excitatory amino acid (EAA) neurotransmitters such as glutamate and aspartate also may contribute to epileptic seizures and to central nervous system (CNS) injury consequent to seizures [9-13]. EAA neurotransmitters are the principal excitatory neurotransmitters in mammalian brain and participate prominently in normal hippocampal function [14]. EAA receptor agonists are also potent convulsants and neurotoxins $[13,15-17]$. Local injection of EAA receptor agonists and stimulation of glutamatergic afferent pathways produce a pattern of acute and chronic morphological changes in the rat hippocampus that are similar to the changes found in the hippocampus of patients with TLE [17-25]. EAA receptor antagonists possess anticonvulsant properties and prevent the morphological changes associated with seizures $[13,16,26-28]$. EAA receptors may be involved in the formation of epileptogenic foci since antagonists of EAA receptors suppress the development of spontaneous seizures and associated neurochemical changes produced by kindling, a model of TLE [29-33]. Direct evidence to support the role of EAA in human epilepsy, however, is limited [34-37].

The current study is based on the hypothesis that binding to EAA and inhibitory amino acid (IAA) neurotransmitter receptors may be altered in epileptic brain tissue of patients with TLE. We measured binding to receptors associated with the $N$-methyl-Daspartate (NMDA) receptor/channel complex, the quisqualate-type EAA receptors, and the $\mathrm{GABA}_{\mathrm{A}^{-}}$ benzodiazepine complex IAA-type receptors in hippo-
From the Departments of *Neurology, $\uparrow$ Neurosurgery, and $\ddagger$ Pathology, University of Michigan, Ann Arbor, MI, and the Department of \$Neurology and Pediatrics and "Pathology, Johns Hopkins University School of Medicine and the *** Kennedy Institute, Baltimore, MD.
Received Oct 18, 1989, and in revised form Jun 25 and Sep 19, 1990. Accepted for publication Nov 19, 1990.

Address correspondence to Dr Johnston, The Kennedy Institute, Room 506, 707 North Broadway, Baltimore, MD 21205. 


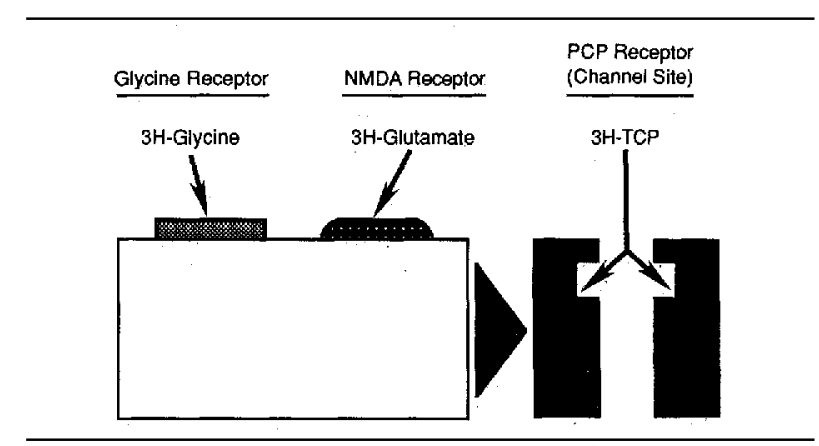

Fig 1 . The receptor components that comprise the NMDA receptorl channel complex. The NMDA recognition site can be selectively labeled with $\left(^{3} H\right)$ glutamate. Activation of the glycine modulatory site markedly enhances receptor/channel activation. $\left({ }^{3} H\right)$ Glycine can be used to selectively label this site. The pbencyclidine (PCP) analogues, tritiated thienyl derivative of PCP (TCP) and $M K-801$, reduce receptor/channel activation by binding to a site within the channel. The binding site can be labeled selectively with $\left.{ }^{3} H\right) T C P$

campal tissue resected from patients with medically refractory TLE and from comparably aged postmortem control specimens.

The regional distribution of EAA and IAA receptors in brain can be imaged and studied quantitatively by labeling each receptor with a tritiated ligand under conditions selective for each receptor type. The NMDAtype EAA receptor/channel complex is comprised of several regulatory binding sites (Fig 1) [38]. The NMDA recognition site can be selectively labeled, un- der appropriate conditions, with $\left[{ }^{3} \mathrm{H}\right]$ glutamate. The associated glycine modulatory site can be measured with $\left[{ }^{3} \mathrm{H}\right]$ glycine. The tritiated thienyl detivative of phencyclidine (TCP) selectively labels a binding site located within the NMDA receptor-associated ionophore. The quisqualate-subrype of EAA receptors can be measured with $\left[^{3} \mathrm{H}\right.$ lglutamate under selective conditions. The modulatory receptors comprising the $\mathrm{GABA}_{\mathrm{A}}$ receptor/ionophore complex can be measured with $\left[{ }^{3} \mathrm{H}\right]$ muscimol to label the $\mathrm{GABA} \mathrm{A}_{\mathrm{A}}$ recognition site and $\left[{ }^{3} \mathrm{H}\right]$ flunitrazepam to label the associated benzodiazepine site [39].

\section{Materials and Methods}

We studied 8 patients ( 4 males and 4 females) with medically refractory TLE whose seizure focus originated unilaterally (Table 1). The anterior $2 \mathrm{~cm}$ of the hippocampus was resected from these patients. Control hippocampus was obtained at autopsy from 8 subjects ( 4 males and 4 females) who had no reported history of neurological or psychiatric disease (mean age \pm standard error of mean, $46 \pm 5$ years; postmortem delay, $11 \pm 2$ hours). Hippocampal tissue was examined by a neuropathologist (P. E. M.) to determine an anatomical diagnosis, and neuronal loss was rated qualitatively.

\section{Materials}

$\left[{ }^{3} \mathrm{H}\right] \mathrm{TCP}$ was obtained from New England Nuclear (Wilmington, DE). $\left[{ }^{3} \mathrm{H}\right]$ Glutamate, $\left[{ }^{3} \mathrm{H}\right] g$ lycine, $\left[{ }^{3} \mathrm{H}\right]$ muscimol, and $\left[{ }^{3} \mathrm{H}\right]$ flunitrazepam were obtained from Amersham (Arlington Heights, IL). All the unlabeled compounds were purchased from commercial sources.

Table 1. Clinical Characteristics and Neuropatbological Findings of Patients with Temporal Lobe Epilepsy

\begin{tabular}{|c|c|c|c|c|c|c|c|c|c|}
\hline $\begin{array}{l}\text { Patient } \\
\text { No. }\end{array}$ & Sex & Age (yr) & $\begin{array}{l}\text { Side } \\
\text { Resected }\end{array}$ & $\begin{array}{l}\text { Age at } \\
\text { Seizure } \\
\text { Onset } \\
(y r)\end{array}$ & $\begin{array}{l}\text { Initial } \\
\text { Febrile } \\
\text { Seizure }\end{array}$ & $\begin{array}{l}\text { Duration of } \\
\text { Frequent } \\
\text { Seizures } \\
\text { (yr) }\end{array}$ & $\begin{array}{l}\text { Seizure } \\
\text { Frequence } \\
\text { at Time of } \\
\text { Surgery }\end{array}$ & $\begin{array}{l}\text { Medications } \\
\text { at Time of } \\
\text { Surgery }\end{array}$ & Pathology \\
\hline 1 & F & 29 & $\mathrm{~L}$ & 0.5 & Yes & 21 & $\begin{array}{l}\text { 4/wk, CPS } \\
1 / \mathrm{mo}, \mathrm{GTC}\end{array}$ & $\begin{array}{l}\text { PHT } \\
\text { P }\end{array}$ & $\begin{array}{l}\text { CA1 } \\
\text { Neuronal loss }\end{array}$ \\
\hline 2 & $\mathrm{~F}$ & 29 & $\mathbf{R}$ & 13 & No & 16 & $3 / w k$, CPS & $\begin{array}{l}\text { PHT } \\
\text { CBZ }\end{array}$ & Astrocytoma, grade 1 \\
\hline 3 & $\mathrm{~F}$ & 20 & $\mathrm{~L}$ & 4 & No & 16 & $3 / w k, C P S$ & $\begin{array}{l}\text { CBZ } \\
\text { VPA }\end{array}$ & Astrocytoma, grade 1 \\
\hline 4 & M & 28 & $\mathrm{~L}$ & 2 & No & 16 & $\begin{array}{l}1 / \mathrm{wk}, \text { SPS } \\
1 / \mathrm{mo}, \mathrm{CPS}\end{array}$ & PHT & $\begin{array}{l}\text { Neuronal loss and } \\
\text { gliosis } \\
\text { CA1, calcification } \\
\text { CA4 }\end{array}$ \\
\hline 5 & M & 60 & $\mathrm{~L}$ & 1 & Yes & 40 & $\begin{array}{l}\text { 1.5/mo, } \\
\text { CPS } \\
8 / \mathrm{mo}, \text { SPS }\end{array}$ & PHT & Not available \\
\hline 6 & $\mathrm{~F}$ & 18 & $\mathbf{R}$ & 9 & No & 6 & 8/mo, CPS & $\begin{array}{l}\text { CBZ } \\
\text { VPA }\end{array}$ & Oligodendroglioma \\
\hline 7 & M & 43 & L & 0.5 & Yes & 34 & 3/wk, CPS & $\mathrm{CBZ}$ & Not available \\
\hline 8 & M & 27 & $\mathrm{~L}$ & 1 & Yes & 20 & 3/wk, CPS & $\mathrm{CBZ}$ & $\begin{array}{l}\text { Neuronal loss in den- } \\
\text { tate gyrus }\end{array}$ \\
\hline
\end{tabular}

CPS = complex partial seizures; GTC = generalized tonic-clonic seizures; SPS = simple partial seizures; PHT = phenytoin; $\mathrm{P}=$ primidone; $\mathrm{CBZ}=$ carbamazepine; $\mathrm{VPA}=$ valproic acid. 


\section{Tissue Preparation}

Once obtained, hippocampal specimens from patients with TLE and autopsy control subjects were quickly frozen on dry ice, stored at $-70^{\circ} \mathrm{C}$, and mounted on cryostat chucks. Mounted specimens were allowed to equilibrate to the temperature of the cryostat $\left(-12\right.$ to $\left.-20^{\circ} \mathrm{C}\right)$ and $20-\mu \mathrm{m}$ frozen sections were cut and thaw-mounted onto gelatin-coated slides. Binding to each type of receptor was carried out in adjacent serial sections from each specimen. Total receptor binding and nonspecific binding were determined in at least 3 sections per specimen per each receptor assay. In order to remove endogenous neurotransmitters and modulatory ligands, all sections underwent a prewash for 30 minutes at $4^{\circ} \mathrm{C}$ in the indicated buffer and were blown dry under a stream of air at room temperature prior to receptor labeling. The sections were incubated with radioactive ligands at subsacurating concentrations for periods of time shown previously to allow equilibrium conditions to be reached. During the incubation period, sections were placed in cytomailers containing the ${ }^{3} \mathrm{H}$ Hligand (final volume, $8 \mathrm{ml}$ ); under these conditions less than $5 \%$ of free ligand is bound.

\section{NMDA Recognition Site Binding Assay}

The EAA receptor agonist ${ }^{3} \mathrm{H}$ ]glutamate was used to label the NMDA-type EAA receptor recognition site under conditions that select for binding to NMDA recognition sites [ 40 , 41]. Sections were prewashed for 30 minutes at $4^{\circ} \mathrm{C}$ in 50 $\mathrm{mM}$ Tris-acetate ( $\mathrm{pH} 7.4$ ) to remove endogenous EAA neurotransmitters, and were dried under a stream of air at room temperature. Subsequently, sections were incubated for 45 minutes in $50 \mathrm{mM}$ Tris-acetate $\left(4^{\circ} \mathrm{C}, \mathrm{pH} 7.4\right)$ containing 2.5 $\mu \mathrm{M}$ quisqualate and $40 \mathrm{nM}\left[{ }^{3} \mathrm{H}\right]$ glutamate to label NMDA recognition sites selectively. Since glutamate binds to both NMDA and quisqualate receptors, a $2.5 \mu \mathrm{M}$ concentration of quisqualate, which saturates quisqualate receptors, was included in the incubation buffer so that $\left.{ }^{3} \mathrm{H}\right]$ glutamate would selectively label the remaining NMDA-type EAA receptors. A second group of sections was incubated in the above buffer and unlabeled glutamate $(1 \mathrm{mM})$ to determine the level of nonspecific binding. Following incubation, sections were rinsed three times with $2 \mathrm{ml}$ of ice-cold buffer, followed by a final rinse with $2 \mathrm{ml}$ of ice-cold glutaraldehyde $(49 \%)$ acetone mixture $(1: 19 \mathrm{vol} / \mathrm{vol})$, and quickly dried under a stream of warm air to minimize uneven ligand dissociation

\section{Glycine Modulatory Site Binding Assay}

Tissue sections were prewashed in $50 \mathrm{mM}$ Tris-citrate $(\mathrm{pH}$ $7.4,4^{\circ} \mathrm{C}$ ) for 30 minutes to remove endogenous ligands, and then were dried under a stream of air at room temperature. Tissue sections were then incubated in the same buffer $(\mathrm{pH}$ 7.4) containing $100 \mathrm{nM}\left[{ }^{3} \mathrm{H}\right]$ glycine and $100 \mu \mathrm{M}$ strychnine for 35 minutes at $4^{\circ} \mathrm{C}$ [42]. Under these conditions, the saturating concentration of strychnine prevents $\left[{ }^{3} \mathrm{H}\right] \mathrm{glycine}$ from labeling the inhibitory glycine receptor and provides a selective measure of the glycine modulatory sites associated with the NMDA receptor/channel complex [42]. Nonspecific binding was determined in the same buffer in the presence of $1 \mathrm{mM}$ unlabeled glycine and represented less than $10 \%$ of total binding. Following incubation, sections were rinsed three times with $2 \mathrm{ml}$ of ice-cold buffer, followed by a final rinse with $2 \mathrm{ml}$ of ice-cold glutaraldehyde-acetone mixture $(1: 19 \mathrm{vol} / \mathrm{vol})$, and quickly dried under a warm stream of air to optimize the level of specific binding and to minimize uneven ligand dissociation.

\section{Pbencyclidine Receptor (NMDA-Associated \\ Channel Binding Site) Binding Assay}

Sections were prewashed for 30 minutes in $50 \mathrm{mM}$ Trisacetate $\left(\mathrm{pH} 7.4,4^{\circ} \mathrm{C}\right)$ to remove endogenous modulatory compounds, and sections were dried under a stream of air at room temperature. Phencyclidine (PCP) receptors were labeled with the selective PCP receptor ligand $\left[{ }^{3} \mathrm{H}\right] \mathrm{TCP}$. Tissue sections were incubated with $\left.30 \mathrm{nM}{ }^{3} \mathrm{H}\right] \mathrm{TCP}$ in $50 \mathrm{mM}$ Tris-acetate plus $1 \mathrm{mM}$ magnesium $\left(\mathrm{Mg}^{2+}\right)$ acetate for 45 minutes at $4^{\circ} \mathrm{C}(\mathrm{pH} 7.4)[41,43]$. Addition of $1 \mathrm{mM} \mathrm{Mg}^{2+}$ to the incubation buffer previously has been shown to maximize the level of $\left[{ }^{3} \mathrm{H}\right] \mathrm{TCP}$ binding in frozen brain sections [43]. With this method, binding equilibrium is achieved by approximately 45 minutes in the presence of $1 \mathrm{mM} \mathrm{Mg}{ }^{2+}$. The level of nonspecific binding was determined by incubating sections in the same buffer containing $20 \mu \mathrm{M}$ unlabeled TCP. The level of nonspecific binding was minimized by subsequently rinsing the sections, after the incubation, three times for 1 minute each with ice-cold buffer. Sections were then rapidly dried under a stream of warm air.

\section{Quisqualate-Type Receptor Binding Assay}

Sections were prewashed for 30 minutes in $50 \mathrm{mM}$ Trishydrochloric acid $(\mathrm{HCl})\left(\mathrm{pH} 7.4,4^{\circ} \mathrm{C}\right)$ to remove endogenous ligands and then dried under a stream of cool air. The quisqualate subtype of EAA receptors was labeled with $\left[{ }^{3} \mathrm{H}\right] \mathrm{glutamate}$ in the presence of a saturating concentration of NMDA to prevent $\left[{ }^{3} \mathrm{H}\right]$ glutamate binding to the NMDA site. This method selectively labels quisqualate receptors in human brain tissue $[40,44]$. Tissue sections were incubated for 45 minutes in $50 \mathrm{mM}$ Tris- $\mathrm{HCl}(\mathrm{pH} \mathrm{7.4)} \mathrm{containing} 100$ $\mu \mathrm{M}$ NMDA and $2.5 \mathrm{mM}$ calcium chloride $\left(\mathrm{CaCl}_{2}\right)$ at $4{ }^{\circ} \mathrm{C}$. Addition of $2.5 \mathrm{mM} \mathrm{CaCl}_{2}$ to the incubation medium selectively maximizes binding to the quisqualate subtype of EAA receptors. The level of nonspecific binding was determined by incubating additional sections in the same incubation buffer plus $1 \mathrm{mM}$ unlabeled glutamate. Subsequently, tissue sections were rinsed three times with $2 \mathrm{ml}$ of ice-cold buffer and one time with ice-cold glutaraldehyde-acetone solution $(1: 19 \mathrm{vol} / \mathrm{vol})$ and rapidly dried under a stream of warm air. Under these conditions, binding in this assay represents mainly postsynaptic neuronal, non-NMDA-type quisqualate receptors [44]. In contrast to binding in membranes, quisqualate receptor binding in the presence of $\mathrm{CaCl}_{2}$ in frozen tissue sections represents postsynaptic high-affinity neuronal binding sites rather than sequestration sites [44].

\section{GABA Receptor Binding Assay}

Tissue sections were prewashed for 30 minutes in $50 \mathrm{mM}$ Tris-citrate $\left(\mathrm{pH} 7.0,4^{\circ} \mathrm{C}\right)$ to remove endogenous ligands and were dried under a stream of cool air. $G_{A B A_{A}}$ receptors were labeled with the selective $G A B A_{A}$ receptor ligand $\left[{ }^{3} \mathrm{H}\right]$ muscimol [45]. Sections were incubated for 30 minutes in $50 \mathrm{mM}$ Tris-citrate $\left(\mathrm{pH} .7 .0,4^{\circ} \mathrm{C}\right.$ ) containing $50 \mathrm{nM}$ $\left[{ }^{3} \mathrm{H}\right]$ muscimol. The level of nonspecific binding was deter- 
mined in the presence of $100 \mu \mathrm{M} \mathrm{GABA}$. Following incubation, sections were rinsed four times with $2 \mathrm{ml}$ of ice-cold buffer and rapidly dried under a stream of warm air.

\section{Benzodiazepine Receptor Binding Assay}

Sections were prewashed three times for 5 minutes each at $4^{\circ} \mathrm{C}$ in $50 \mathrm{mM}$ Tris-citrate ( $\mathrm{pH} 7.0$ ) to remove endogenous ligands and dried under a stream of cool air. Benzodiazepine receptors associated with $\mathrm{GABA}_{\mathrm{A}}$ receptor/channel complexes were labeled with the selective benzodiazepine receptor ligand $\left\{{ }^{3} \mathrm{H}\right\}$ flunitrazepam $[46,47]$. Sections were incubated for 30 minutes in $50 \mathrm{mM}$ Tris-citrate $\left(\mathrm{pH} 7.0,4^{\circ} \mathrm{C}\right.$ ) plus $10 \mathrm{nM}\left[{ }^{3} \mathrm{H}\right]$ flunitrazepam. Nonspecific binding was determined in the presence of the benzodiazepine receptor ligand clonazepam ( $1 \mathrm{mM}$ ). Following incubation, sections were rinsed two times for 5 minutes each in ice-cold buffer and rapidly dried with a stream of warm air.

\section{Data Collection and Analysis}

Tissue sections were apposed to tritium-sensitive film (LKB Ultrafilm 3H; Pharmacia Co, Bromma, Sweden) for 1 to 8 weeks. A set of radioactive standards (American Radiochemicals, St Louis, MO; ARC 3H) calibrated against brain pastes with known amounts of tritium was exposed with each film. Quantitative analysis of the resulting autoradiograms was performed densitometrically with a microcomputer-based video densitometer system (Imaging Research, St Catharines, Ontario, Canada) [45]. Optical density values were converted to $\mathrm{pmol} / \mathrm{mg}$ of protein values with a computer-generated polynomial regression analysis that compared film densities produced by the tissue sections to those of radioactive standards. Ten readings per area were averaged and means of averaged readings from 3 to 5 sections per patient per receptor assay were compared to corresponding values for control subjects. Four hippocampal regions were examined: stratum lacunosum moleculare and stratum pyramidale of cornu ammonis 1 (CA1), area CA4 (hilus), and stratum moleculare of the dentate gyrus. Other hippocampal areas were not consistently present in resected tissue from patients with TLE. Receptor binding data represent specific binding (total minus nonspecific binding) and are presented as mean \pm SEM in density units (fmol/mg of protein). Statistical comparisons were made with one-way analysis of variance (ANOVA).

\section{Results}

Table 1 contains a summary of the clinical characteristics and neuropathological findings of the 8 patients with TLE. The mean age ( \pm SEM) of the patients with TLE at the time of surgery was $32 \pm 5$ years compared to $46 \pm 5$ years for the autopsy control subjects ( $\mathrm{n}=$ 8). The range of ages in both groups was similar (TLE, 18 to 60 years; controls, 22 to 61 years). Four of the 8 patients with TLE were male. In 6 of the 8 patients with TLE, seizures originated from the left hemisphere. The initial age of onset of seizures occurred in the first postnatal year in 4 of the 8 patients with TLE and these seizures were all associated with febrile convulsions. The duration of the seizure disorder ranged from 6 to
40 years (mean \pm SEM, $21 \pm 4$ years). The patients with TLE were taking single or multiple anticonvulsant drugs (see Table 1). At the time of surgery, the patients received multiple different medications, including thiamylal (Surital), fentanyl, droperidol, and labetalol, as well as the anesthetics nitrous oxide, isoflurane (Forane). One patient received morphine, and another, lorazepam. Although hippocampal neuronal loss was not examined quantitatively in this study, qualitative analysis of the hippocampi in the patients with TLE by a neuropathologist (P. E. M.) revealed mild astroglial proliferation and loss of pyramidal and granule cells in the majority of patients. Severe cell loss in the hippocampal subfields and in the hilus, typical of Ammon's horn sclerosis, was not evident in any of the patients. Three patients had extrahippocampal temporal lobe tumors: 2, grade 1 astrocytomas; and 1, oligodendroglioma.

\section{NMDA Recognition Site Binding}

Regionally selective increases in binding to the NMDA recognition site were observed in the surgical hippocampal specimens compared to autopsy control brains (Table 2, Figs 2 and 3). Significant mean increases in NMDA recognition site binding were found in stratum lacunosum moleculare and stratum pyramidale of hippocampal area CA1, and in stratum moleculare of the dentate gyrus but not in the CA4 subfield of the hippocampi of patients with TLE, compared to autopsy control subjects. Elevated levels of NMDA recognition site binding were not found in all TLE specimens: 1 TLE specimen exhibited levels of NMDA receptor binding lower than the mean level in autopsy control subjects. The interspecimen variability in receptor binding was greater in the TLE group than in the autopsy control subjects.

\section{Glycine Modulatory Site Binding}

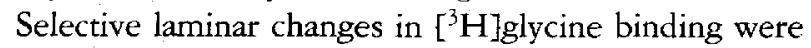
observed in the CA1 hippocampal subfield (see Table 2 and Fig 3). In the TLE group, glycine modulatory site binding was significantly increased in stratum lacunosum moleculare but the level of binding in stratum pyramidale was equivalent to the level in autopsy control subjects. Binding in stratum moleculare in the dentate gyrus of TLE specimens was significantly elevated relative to binding in autopsy control subjects. In contrast, equivalent binding densities were observed in hippocampal subfield CA4 of TLE and control groups. The variation in $\left[{ }^{3} \mathrm{H}\right]$ glycine binding in both TLE and autopsy groups was greater than for any of the other binding assays and the degree of variation in the TLE group was especially pronounced. In fact, $\left[{ }^{3} \mathrm{H}\right]$ glycine binding densities in several patients with TLE were below the corresponding mean binding densities of the autopsy control subjects. 


\begin{tabular}{|c|c|c|c|c|}
\hline \multirow[b]{2}{*}{ Receptor Binding } & \multicolumn{3}{|c|}{ Hippocampal Region } & \multirow[b]{2}{*}{$\begin{array}{l}\text { Stratum Moleculare } \\
\text { of Dentate Gyrus }\end{array}$} \\
\hline & $\begin{array}{l}\text { Stratum Lacunosum } \\
\text { Moleculare of CA1 }\end{array}$ & $\begin{array}{l}\text { Stratum Pyramidale of } \\
\text { CA } 1\end{array}$ & CA4 & \\
\hline \multicolumn{5}{|l|}{ NMDA } \\
\hline Control & $175 \pm 15$ & $480 \pm 46$ & $96 \pm 13$ & $288 \pm 43$ \\
\hline TLE & $\begin{array}{l}365 \pm 48^{b} \\
(+108 \%)\end{array}$ & $\begin{array}{l}702 \pm 84^{c} \\
(+46 \%)\end{array}$ & $\begin{array}{l}145 \pm 51 \\
(+51 \%)\end{array}$ & $\begin{array}{l}610 \pm 71^{d} \\
(+111 \%)\end{array}$ \\
\hline \multicolumn{5}{|c|}{ Glycine (strychnine-insensitive) } \\
\hline Control & $469 \pm 45$ & $1093 \pm 72$ & $304 \pm 33$ & $675 \pm 67$ \\
\hline TLE & $\begin{array}{l}801 \pm 137^{c} \\
(+71 \%)\end{array}$ & $\begin{array}{c}1231 \pm 186 \\
(+13 \%)\end{array}$ & $\begin{array}{l}344 \pm 95 \\
(+13 \%)\end{array}$ & $\begin{array}{c}1065 \pm 162^{c} \\
(+57 \%)\end{array}$ \\
\hline \multicolumn{5}{|l|}{ Phencyclidine } \\
\hline Control & $122 \pm 18$ & $373 \pm 27$ & $112 \pm 10$ & $247 \pm 29$ \\
\hline TIE & $\begin{array}{l}79 \pm 10 \\
(-35 \%)\end{array}$ & $\begin{array}{l}209 \pm 25^{1} \\
(-44 \%)\end{array}$ & $\begin{array}{l}33 \pm 7^{d} \\
(-71 \%)\end{array}$ & $\begin{array}{l}163 \pm 23^{c} \\
(-34 \%)\end{array}$ \\
\hline \multicolumn{5}{|l|}{ Quisqualate } \\
\hline Control & $298 \pm 25$ & $487 \pm 29$ & $201 \pm 16$ & $520 \pm 40$ \\
\hline TLE & $\begin{array}{l}486 \pm 81^{c} \\
(+63 \%)\end{array}$ & $\begin{array}{l}598 \pm 89 \\
(+23 \%)\end{array}$ & $\begin{array}{l}174 \pm 49 \\
(-14 \%)\end{array}$ & $\begin{array}{l}589 \pm 72 \\
(+13 \%)\end{array}$ \\
\hline \multicolumn{5}{|l|}{$\mathrm{GABA}_{\mathrm{A}}$} \\
\hline Control & $3250 \pm 281$ & $4843 \pm 357$ & $1279 \pm 122$ & $4603 \pm 350$ \\
\hline TLE & $\begin{array}{c}1803 \pm 279^{b} \\
(-45 \%)\end{array}$ & $\begin{array}{c}3180 \pm 382^{\mathrm{b}} \\
(-34 \%)\end{array}$ & $\begin{array}{l}533 \pm 183^{b} \\
(-58 \%)\end{array}$ & $\begin{array}{l}3933 \pm 431 \\
(-15 \%)\end{array}$ \\
\hline \multicolumn{5}{|l|}{ Benzodiazepine } \\
\hline Control & $966 \pm 92$ & $1161 \pm 68$ & $480 \pm 45$ & $1197 \pm 40$ \\
\hline TLE & $\begin{array}{l}790 \pm 93 \\
(-18 \%)\end{array}$ & $\begin{array}{l}820 \pm 87^{b} \\
(-29 \%)\end{array}$ & $\begin{array}{l}262 \pm 77^{\circ} \\
(-45 \%)\end{array}$ & $\begin{array}{c}1107 \pm 86 \\
(-7 \%)\end{array}$ \\
\hline
\end{tabular}

${ }^{2}$ Values represent mean \pm SEM (fmol bound $/ \mathrm{mg}$ of protein). Values in parentheses represent percent change in mean receptor binding in hippocampus of patients with TLE relative to control subjects.

$b_{p}<0.01$.

$c p<0.05$.

$\mathrm{d}_{p}<0.001$.

\section{Pbencydidine Receptor (Channel Site) Binding}

$\left[{ }^{3} \mathrm{H}\right] \mathrm{TCP}$ binding to the NMDA-associated ionophore was consistently decreased in all four hippocampal regions of specimens from patients with TLE, compared with autopsy control values (see Table 2, Figs 2 and 3). The largest decrease was observed in the CA4 subfield, with smaller decreases in other hippocampal regions. Variation in PCP receptor binding between specimens was equivalent for TLE and autopsy control groups and was the smallest observed among the different binding assays. PCP binding densities were uniformly lower in specimens from patients with TLE than corresponding mean densities of the autopsy control group.

Comparison of Relative Changes in NMDA, Glycine, and Pbencyclidine Receptor Binding

Figure 4 illustrates the relative changes in binding to three components of the NMDA receptor/channel complex within individual patients with TLE. In stratum lacunosum moleculare of CA1, the pattern of relative changes in NMDA, glycine, and PCP receptor binding was consistent between patients with TLE. The elevations of NMDA binding paralleled the changes in glycine receptor binding in patients with TLE. PCP receptor binding was consistently reduced in patients with TLE. Similar relative changes were observed in the other hippocampal areas examined.

\section{Quisqualate-Type Receptor Binding}

$\left[{ }^{3} \mathrm{H}\right]$ Glutamate binding to quisqualate-preferring receptors in stratum lacunosum moleculare of CAI was significantly elevated in patients with TLE, compared with autopsy specimens (see Table 2 and Fig 3). A similar trend was observed in stratum pyramidale of CA1, but the results were not statistically significant. However, equivalent binding densities were observed between specimens from patients with TLE and autopsy control subjects in the CA4 subfield and in stratum moleculare of the dentate gyrus. Interspecimen variation in binding densities was greatest in the TLE group, compared with the autopsy group.

\section{$G A B A_{A}$ Receptor Binding}

The changes in IAA receptor binding in the hippocampus of patients with TLE were different from those in EAA binding (Figs 5 and 6; see Table 2). $\mathrm{GABA}_{\mathrm{A}}$ receptor binding was significantly reduced in both lami- 

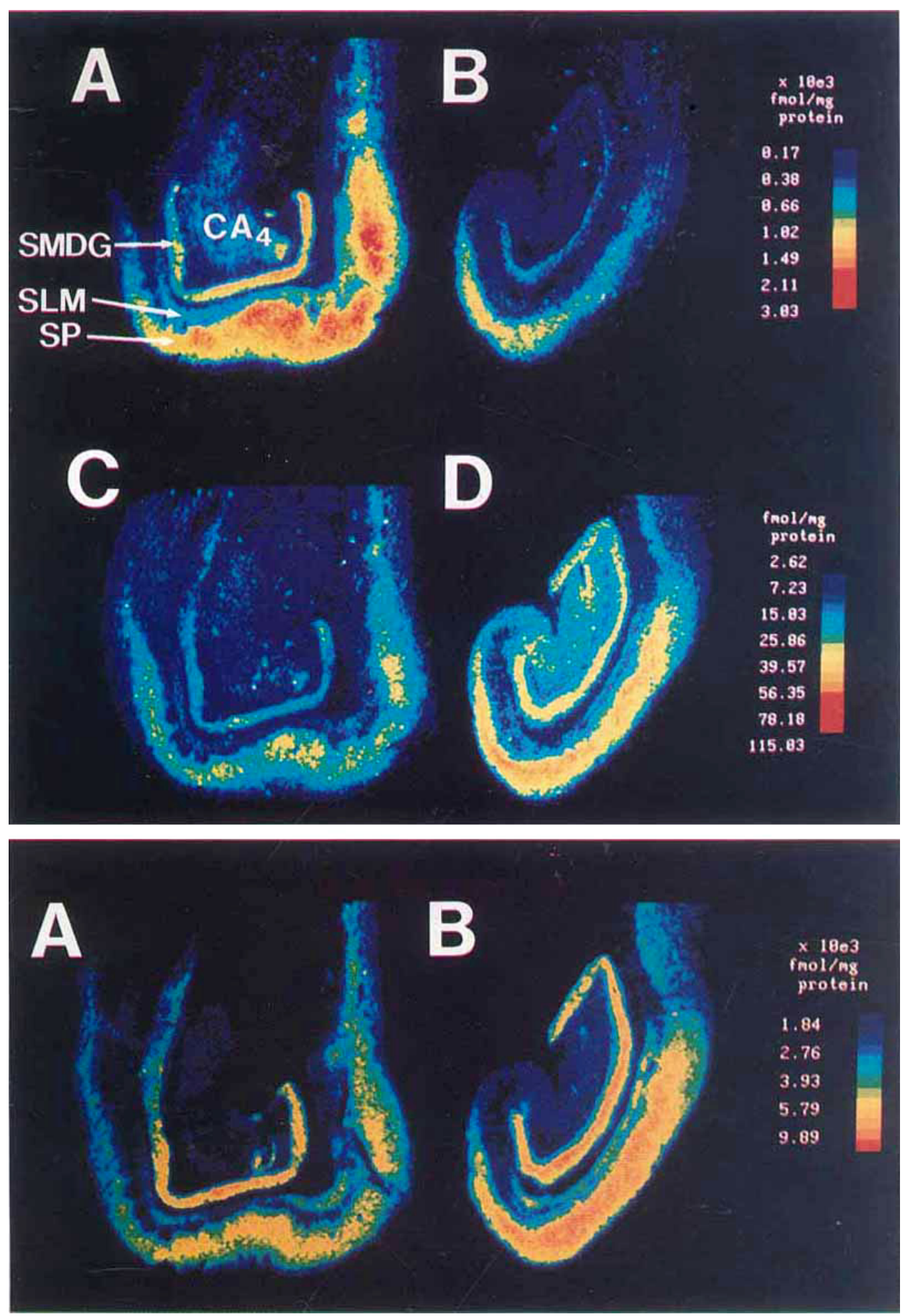

Fig 2. Quantitative autoradiograms of NMDA $(A, B)$ and phencyclidine (PCP) $(C, D)$ receptor binding in the bippocampus of patients with temporal lobe epilepsy (TLE) (A, C) and control subjects $(B, D)$. NMDA receptors were labeled with $40 \mathrm{nM}$ $\left.f^{3} \mathrm{H}\right)$ glutamate in $50 \mathrm{mM}$ Tris-acetate plus $2.5 \mu \mathrm{M}$ quisqualate. $P C P$ receptors were labeled with $40 n M\left({ }^{3} H\right) T C P$ (tritiated thienyl derivative of $P(P)$ in $50 \mathrm{mM}$ Tris-acetate and $1 \mathrm{mM}$ magnesium acetate. Note that the color scale bars for $N M D A$ and $P C P$ receptor binding are different. $N M D A$ and $P C P$ receptor binding bave similar regional distributions in control specimens.
Fig 5. Quantitative autoradiograms of $G A B A_{A}$ receptor binding in the bippocampus of patients with temporal lobe epilepsy (TLE) (A) and autopsy controls (B). GABA receptors were labeled with $\left.50 \mathrm{nM} \mathrm{f}^{3} \mathrm{H}\right)$ muscimol in $50 \mathrm{mM}$ Tris-citrate. 
S. Mol. CA1 Subfield

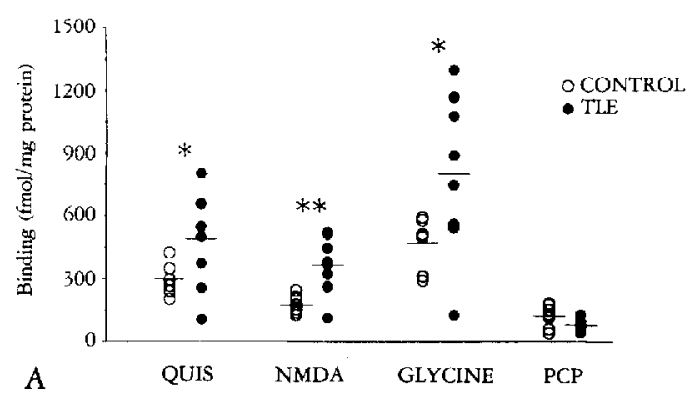

CAA Subfield

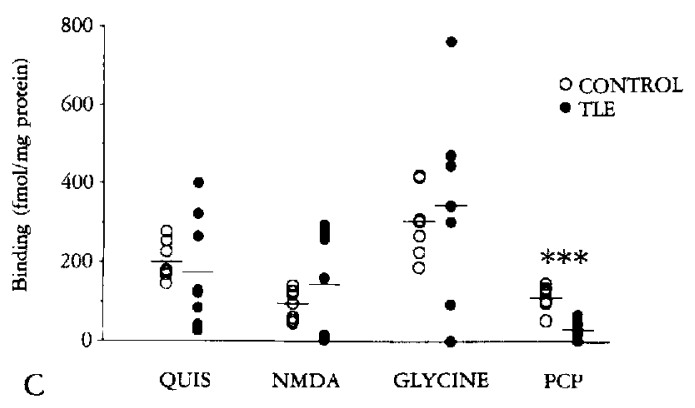

S. Pyr. CA1 Subfield

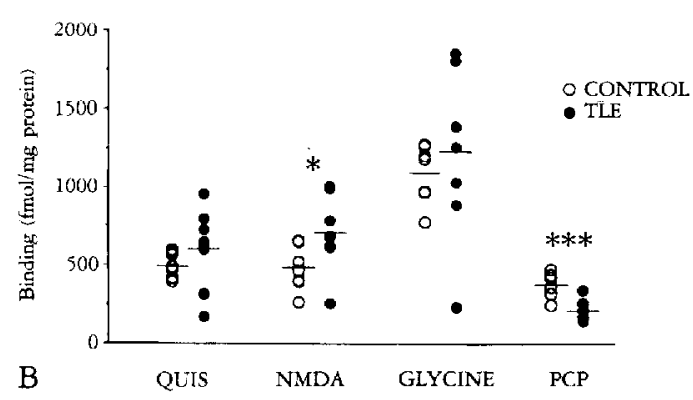

S. Mol. Dentate Gyrus

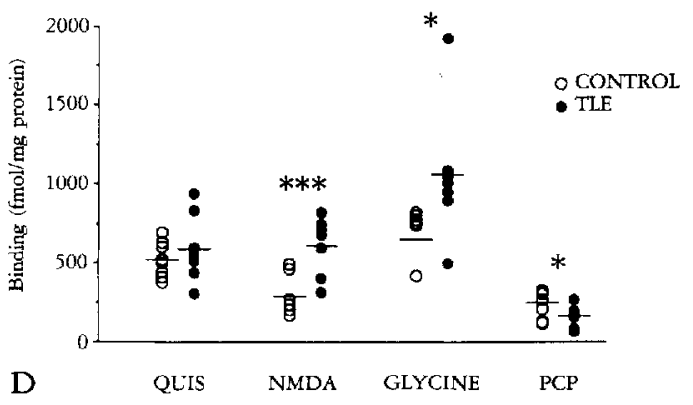

Fig 3. Histograms of excitatory amino acid receptor binding. (A) Stratum lacunosum moleculare of $C A 1,(B)$ stratum pyramidale of CA1, (C) CA4, and (D) stratum moleculare in the dentate gyrus of hippocampi from patients with cbronic temporal lobe epilepsy (TLE) and from age-matched autopsy control subjects. Binding to quisqualate-type glutamate receptors (QUIS) and to three receptors comprising the NMDA receptor channel complex (NMDA recognition site, glycine modulatory site, and phencydidine [PCP] receptor) was measured in adjacent frozen sections with in vitro receptor autoradiography. Data represent binding densities in hippocampal regions from individual patients. Horizontal lines indicate the mean values for each group. Hippocampi from 8 patients with TLE and from 8 autopsy control subjects were used for each receptor assay. ${ }^{*} \mathrm{p}<0.05,{ }^{* *} \mathrm{p}<0.01,{ }^{* * *} \mathrm{p}$ $<0.001$, TLE versus control, one-way ANOVA.

nae of the CA1 subfield and in the CA4 subfield in the hippocampus of patients with TLE, compared with autopsy control subjects. Binding densities, however, were equivalent between the groups in the stratum moleculare of the dentate gyrus. The degree of $\mathrm{GABA}_{\mathrm{A}}$ receptor binding variability between specimens was similar for both TLE and autopsy control groups.

\section{Benzodiazepine Receptor Binding}

The regional changes in benzodiazepine receptor binding between TLE and autopsy groups paralleled the regional changes in $\mathrm{GABA}_{\mathrm{A}}$ receptor binding (see Table 2, and Figs 5 and 6); however, there was a nonsignificant trend for the magnitude of these changes to be smaller. $\left[{ }^{3} \mathrm{H}\right]$ Flunitrazepam binding to benzodiazepine

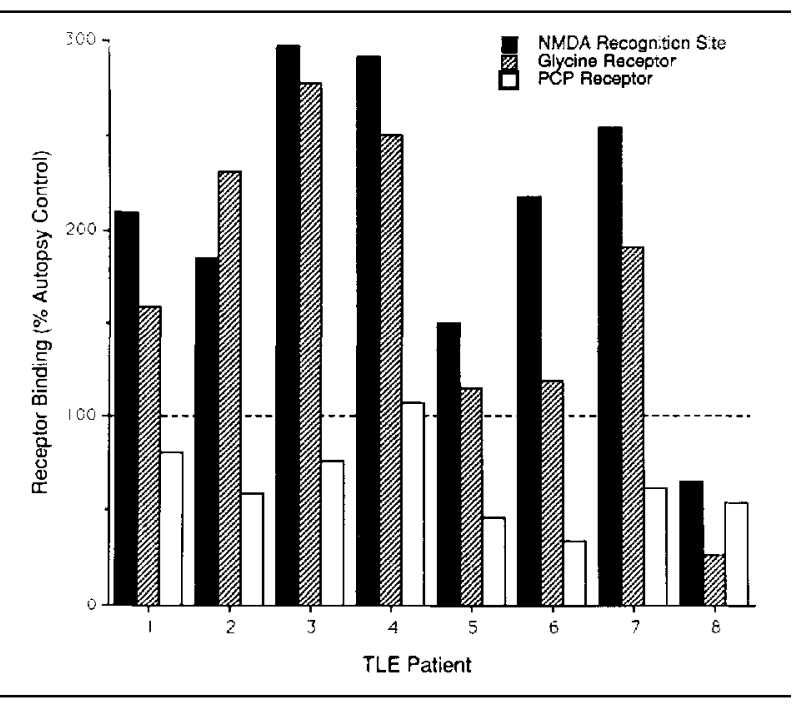

Fig 4. Comparison of relative binding to NMDA, glycine, and phencyclidine (PCP) receptors witbin temporal lobe epilepsy (TLE) specimens. Mean receptor binding in stratum moleculare in $C A 1$ is expressed as a percent of mean binding in autopsy controls. The patient numbers correspond to the patient numbers listed in Table 1. 


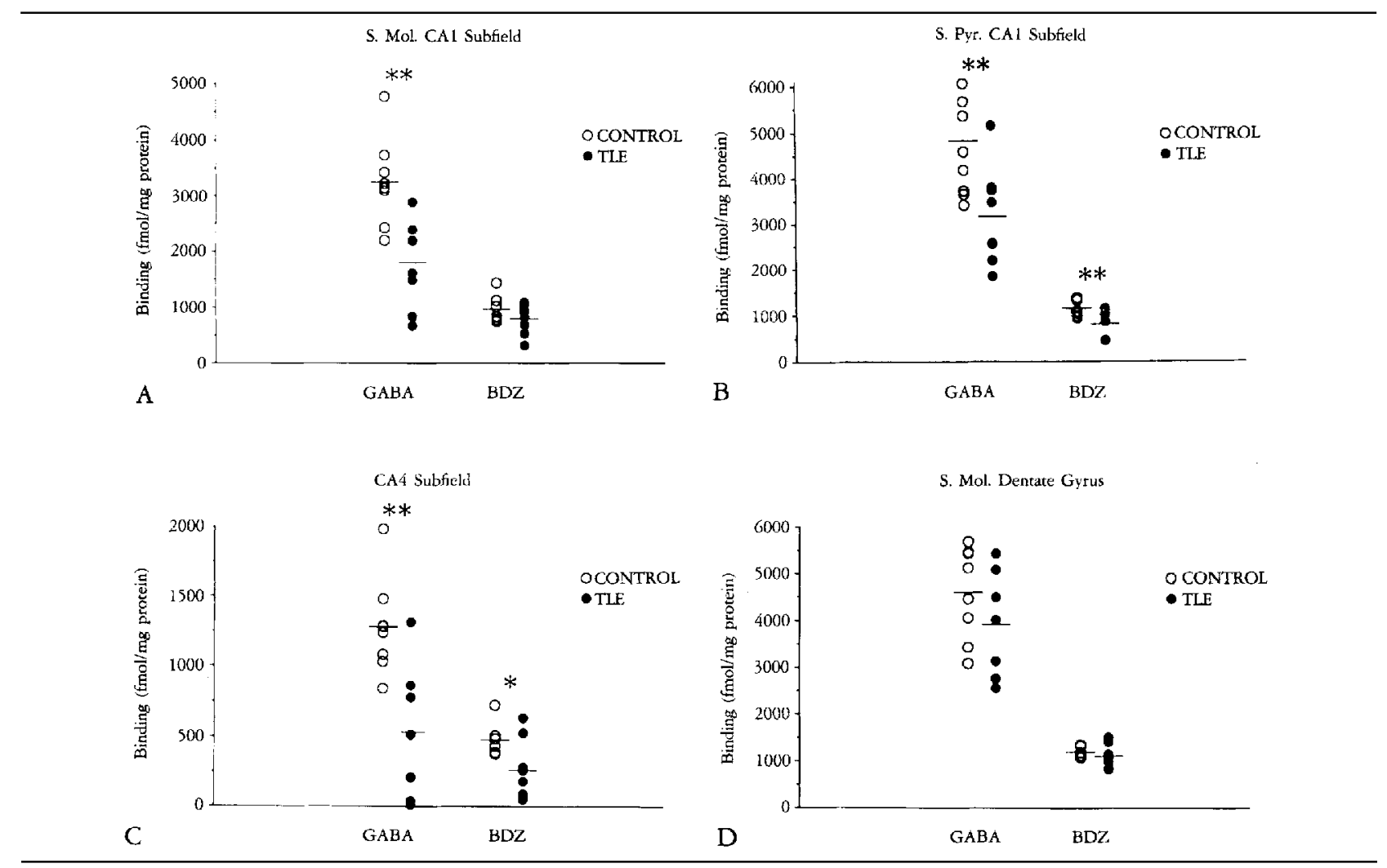

Fig 6. Histograms of inbibitory amino acid (IAA) receptor binding (GABA $A_{A}$ and benzodiazepine $[\mathrm{BDZ}]$ receptors) in four bippocampal regions from patients with temporal lobe epilepsy (TLE) and from age-matched autopsy controls ( $n=7 /$ graup). IAA receptors were labeled in sections adjacent to those used to label excitatory amino acid receptors (see Fig 3). Data points represent binding densities in individual patients and borizontal lines indicate mean binding densities/group. (A) Stratum lacunosum moleculare of CA1. (B) Stratum pyramidale of CA1. (C) CA4. (D) Stratum moleculare of the dentate gyrus. ${ }^{*} \mathrm{p}<0.05,{ }^{* *} \mathrm{p}<0.01,{ }^{* * *} \mathrm{p}$ $<0.001$.

receptors was significantly reduced in stratum pyramidale of CA1 $(-29 \%)$ with a similar trend in stratum lacunosum moleculare of $\mathrm{CA} 1$. Binding densities were similar between groups in stratum moleculare of the dentate gyrus. A significant decrease in binding was observed in TLE CA4 subfield ( $-45 \%$ ), compared to autopsy controls. The variability in binding between specimens was similar in TLE and control groups.

\section{Discussion}

We examined the hypothesis that EAA and IAA neurotransmitter receptor binding are altered in hippocampal tissue removed from patients with TLE. The hippocampal tissue examined in these studies contained pathological evidence of neuronal loss but not advanced mesial temporal sclerosis. Using quantitative receptor autoradiography, we found that EAA and IA A receptor binding were differentially altered in the

hippocampus of patients with TLE, compared with autopsy control subjects. The observation that binding to IAA ( $G A B A_{A}$ and benzodiazepine) receptors was reduced is consistent with previous observations [4]. Similarly, the reduction in binding to the PCP receptor site located within the excitatory NMDA receptor channel was reported in a recent preliminary communication [48]. The novel observation made in this study is that the density of NMDA-type EAA receptor sites and glycine modulatory sites was increased in the same tissue in which binding to the PCP channel receptor was reduced. Thus, we found two possible neurotransmitter receptor alterations that could contribute to enhanced neuronal excitability: a reduction in IAA receptor binding and an increase in the ratio of NMDA and glycine-type EAA receptors to PCP-type receptors within the NMDA receptor-operated channel. Although this is the first report of an increase in the ratio of NMDA receptors to PCP receptors in hippocampus from patients with TLE, a similar alteration in the NMDA receptor/channel complex was observed in animal experiments, described below $[49,50]$. This change could contribute to enhanced vulnerability of the TLE hippocampus to progressive neuronal injury.

The experimental methods and design of this study have some limitations. Both the small number of specimens and the inherent problems of neuropathological variability associated with studies of chronic neurologi- 
cal brain disorders limit the interpretation of the data. Because of the relatively small number of specimens per group, the effects of possible confounding variables such as the effects of postmortem delay on receptor binding in autopsy control specimens or the effects of chronic medication on receptor binding in patients with TLE could not be directly determined. Some evidence suggests that effects of postmortem delay do not substantially alter the results. A previous study with a larger number of autopsy specimens demonstrared no correlation between the postmortem delay period $(0$ to 16 hours) and the density of EAA and IAA receptor binding [ 51$]$. Also, the EAA and IAA receptor binding changes observed in our study were in opposite directions and were regionally selective. This argues against a generalized effect of postmortem delay.

The greater mean age of autopsy control subjects compared with patients with TLE may contribute to the apparent elevation of receptor binding in TLE patients since in a previous study receptor binding densities tended to decrease up to $10 \%$ per decade in humans [51]. Although these age-related differences may contribure to the observed changes, they cannot explain the entire increase in NMDA and glycine receptor binding in patients with TLE (50 to $100 \%$ increase) or the decreased binding to PCP receptors and $\mathrm{GABA}_{\mathrm{A}}$ or benzodiazepine receptors.

The effects of medications may be confounding factors. Rinsing tissue sections prior to receptor labeling should remove perioperative or chronic anticonvulsant medications from the tissue of patients with TLE. Only 1 patient received a medication (morphine) that directly alters EAA and IAA receptor binding [52]. It is likely, however, that chronic anticonvulsant treatment contributed to the changes in receptor binding. Although none of the patients received anticonvulsant compounds whose site of action is at EAA or IAA receptors (except one who received primidone in combination therapy), chronic treatment may indirectly cause regulatory changes in these receptors. Although there is no experimental evidence to support this idea, the effects of chronic anticonvulsant treatment cannot be ruled out.

Another problem was the limited amount of hippocampal tissue available from patients with TLE. This made it impossible to perform detailed kinetic studies to assess whether the changes in equilibrium binding represented changes in receptor affinity or alterations in receptor numbers. In addition, the severity of regional neuronal loss in TLE specimens could not be reliably assessed in the frozen tissue sections. It is unlikely that differences between groups in endogenous neurotransmitters and neuromodulations that bind to EAA and IAA receptors could account for the observed changes in receptor binding since the tissue was prerinsed prior to receptor labeling under conditions that have been demonstrated to minimize potential differences in residual endogenous compounds. However, the binding could reflect the presence of very adhesive molecules such as polyamines. If this is the case, our in vitro observations could reflect physiologically significant alterations in the state of receptors in living tissue.

\section{NMDA Recognition Site Binding}

The pattern of NMDA recognition site binding observed in autopsy control specimens was similar to the pattern of binding observed in previous studies of human and nonhuman primate hippocampus [53-55]. The regionally selective elevation of NMDA receptor binding within the CA1 subfield in stratum lacunosum moleculare and stratum pyramidale in TLE specimens corresponds to the hippocampal fields that receive the majority of EAA neurotransmitter inputs [14]. The enhanced binding in TLE specimens compared to autopsy controls can be related to several mechanisms or combination of mechanisms. The apparent increase in NMDA receptor binding in patients with TLE may represent a selective loss of these receptors in the autopsy control specimens as a result of postmortem delay; however, this seems unlikely based on previous studies $[51,54]$. Alternatively, the enhanced binding may reflect regulatory changes secondary to altered neuronal activity, neuronal injury, adaptive reorganization of neuronal circuits, and/or chronic anticonvulsant treatment. Studies in experimental animals demonstrated that excitotoxic injury or abnormal functional activity in the hippocampus is associated with axonal sprouting and synaptic rearrangement [56-58], and such synaptic rearrangements appear to occur in the hippocampus of patients with TLE [24, 59-61]. Whether these rearrangements are associated with an increase in NMDA receptor binding is not known. We found in a series of animal experiments that the number of NMDA receptor (recognition) sites increases rapidly by as much as $100 \%$ in response to treatment with drugs that block the NMDA-operated channel $[49,62]$.

Previous studies of NMDA receptor (recognition site) binding in human brain tissue from patients with epilepsy yielded conflicting results. NMDA receptor binding was elevated in two preliminary reports of NMDA receptor binding in patients with TLE. In one study, the maximal amount of ligand bound to the NMDA receptor binding was increased 2.5-fold in homogenates prepared from the epileptic focus in temporal cortex compared to nonepileptic temporal cortex of patients with TLE [63]. In a second study, NMDA receptor binding was increased in the entorhinal cortex of TLE specimens compared to autopsy controls, as determined by quantitative receptor autoradiography [64]. Two other preliminary studies suggested that 
the NMDA recognition site binding is reduced in the hippocampus of patients with TLE. Hosford and colleagues [48] reported reduced NMDA-sensitive $\left[{ }^{3} \mathrm{H}\right]$ glutamate binding in the $\mathrm{CA} 3$ subfield of patients with TLE from Ammon's horn sclerosis. In the second study [64], reductions in NMDA receptor binding were reported in the CA1, CA3, and CA4 hippocampal subfields of patients with TLE from Ammon's horn sclerosis. The differences in results may reflect the severity of the neuropathology in the patients examined. In contrast to the extensive neuronal loss in TLE specimens (i.e., Ammon's horn sclerosis) examined in the studies reporting NMDA receptor loss [48, 64], the severity of pathology in our study was not as marked and none of our patients had Ammon's horn sclerosis. Three of the 8 TLE specimens in our study contained low-grade gliomas.

\section{Glycine Modulatory Site Binding}

Previous studies of EAA receptor binding in TLE did not examine strychnine-insensitive $\left[{ }^{3} \mathrm{H}\right]$ glycine binding. The distribution of glycine modulatory site binding paralleled the distribution of NMDA recognition site binding in the hippocampus of autopsy control specimens, which is consistent with previous reports of colocalization of these receptors in human brain [65]. The regionally selective receptor binding changes observed in the hippocampus of patients with TLE paralleled, in general, the increases in NMDA recognition site binding. One exception was in stratum pyramidale of CA1, where only binding to the NMDA recognition site was elevated. The coordinate changes in these two binding sites are consistent with the idea that these two sites are components of the same receptor/channel complex (see Fig 1). The results suggest that these two sites are simultaneously upregulated in the hippocampus of patients with TLE despite neuronal injury and cell loss.

\section{Phencyclidine Receptor (Channel Site) Binding}

The topography of $\left[{ }^{3} \mathrm{H}\right] \mathrm{TCP}$ binding in autopsy control specimens was similar to the pattern of binding to the other two components of the NMDA receptor complex (NMDA and glycine receptors), which is consistent with the idea that these receptors comprise a receptor complex (see Fig 1). The distribution of $\left[{ }^{3} \mathrm{H}\right] \mathrm{TCP}$ binding was similar to the pattern described in previous reports on human hippocampus $[66,67]$. Reduced $\left[{ }^{3} \mathrm{H}\right] \mathrm{TCP}$ binding was found in all four hippocampal regions of patients with TLE compared to control subjects, in contrast to the more selective regional changes found in binding to NMDA and glycine sites. The same factors already mentioned (anticonvulsant treatment, neuronal cell loss and synaptic reorganization, receptor downregulation, and postmortem autolysis in control specimens) could have contributed to these changes. A previous study suggested that postmortem autolysis does not contribute to the results [51]. Chronic anticonvulsant treatment could have contributed to the changes and cannot be ruled out. However, none of the anticonvulsants the patients had taken are known to have effects at the NMDA receptor/channel complex.

\section{Change in the Ratio of NMDA to Phencyclidine Binding Sites}

Binding to the PCP receptor site within the NMDAoperated ion channel is reduced even though binding to the associated NMDA and glycine receptor sites is elevated in the same tissue. This change might be related either to an increase in NMDA and glycine sites not associated with NMDA-operated channels or to an apparent change in the ratio of NMDA and glycine receptor sites to $P C P$ channel sites per receptor/channel complex [68]. There are several experimental precedents for a change in the quantitative relationship between NMDA receptor sites and PCP channel sites. $\left[{ }^{3} \mathrm{H}\right] \mathrm{TCP}$ binding is modulated by NMDA and glycine receptor activation $[69,70]$. The effective coupling between these receptors may be reduced in patients with TLE as has been demonstrated in patients with Alzheimer's disease [ $71-73]$, such that the remaining endogenous glutamate and glycine in the tissue sections is less effective at increasing $\left[{ }^{3} \mathrm{H}\right] \mathrm{TCP}$ binding. It is also possible that multiple genetic forms of NMDA receptor/channel complexes exist, each with a different ratio of NMDA, glycine, and PCP receptors [42]. Our data could reflect an alteration in the relative numbers of these different forms expressed in selected regions of TLE hippocampus.

A third possibility is that the reduction in $\left[{ }^{3} \mathrm{H}\right] \mathrm{TCP}$ binding and increased binding to the NMDA recognition site reflect a reaction to neuronal injury within the hippocampus of patients with TLE and functional expression of cryptic NMDA receptors $[14,22-25$, 53-55, 66, 74, 75]. Damage to dendrites of principal hippocampal neurons could result in a loss of NMDA receptor/channel complexes, reflected in a loss of $\left[{ }^{3} \mathrm{H}\right] \mathrm{TCP}$ binding sites. The enhanced NMDA binding could reflect functional NMDA receptor upregulation secondary to reduction in PCP channel activity. This hyporhesis is supported by our experimental observation that blockade of PCP channels by MK- 801 results in a prompt increase in NMDA receptors in rodents [49].

\section{Quisqualate-Type Receptor Binding}

The regional distribution of quisqualate receptor binding in the hippocampus of control specimens was similar to the pattern described previously [53]. The moderate elevation or maintenance of quisqualate receptor binding in the hippocampus of patients with TLE de- 
spite cell loss suggests that these sites are preserved or possibly upregulated in TLE. Interpretation of these data has the same limitations as that of the data concerning NMDA receptor binding. These data are consistent with findings in several preliminary reports of increased quisqualate receptor binding in hippocampus from patients with epilepsy. In one preliminary study of patients with TLE who had Ammon's horn sclerosis, there was significantly increased quisqualate receptor binding in stratum moleculare of the dentate gyrus and maintained binding in other hippocampal subfields despite extensive cell loss [48]. In a second preliminary study, $\quad\left[{ }^{3} \mathrm{H}\right] \alpha$-amino-3-hydroxy-5-methyl-4-isoxazolepropionic acid (AMPA) binding to a subtype of quisqualate receptors was enhanced in entorhinal cortex, maintained in stratum moleculare of the dentate gyrus, and reduced in CA1, CA3, and CA4 in the context of marked cell loss in the hippocampus of patients with TLE and with Ammon's horn sclerosis [64].

\section{$G A B A_{A}$ and Benzodiazepine Receptor Binding}

The regionally selective reductions in $\mathrm{GABA}_{A}$ and benzodiazepine receptor binding found in patients with TLE are consistent with previous reports of reductions in GABAergic synaptic markers and selective injury and loss of hippocampal neurons [4, 22-25]. Some studies demonstrated no alteration in $\mathrm{GABA}_{\mathrm{A}}$ and benzodiazepine receptor binding in patients with TLE or other forms of epilepsy $[63,76]$. It is possible that the reduction of $\mathrm{GABA}_{\mathrm{A}}$ and benzodiazepine binding in our study may reflect secondary downregulation resulting from neuronal injury or chronic anticonvulsant therapy. The relative contribution of neuronal loss to the decrease in $\mathrm{GABA}_{\mathrm{A}}$ and benzodiazepine receptor binding in specimens from patients with TLE is not addressed by this study. It is unclear from this study whether the trend for a greater reduction in benzodiazepine receptor binding than $\mathrm{GABA}_{\mathrm{A}}$ receptor binding in patients with TLE represents differential receptor regulation or an artifact of the binding assays.

\section{Possible Implications of Altered Excitatory and Inhibitory Amino Acid Receptor Binding}

The increased NMDA and glycine receptor binding and reduced IAA receptor binding observed in TLE specimens could predispose the hippocampus to neuronal hyperexcitability and possibly promote further seizures and neuronal injury. NMDA receptor activation is involved in burst discharges in hippocampal neurons $[35,77-80]$. Sustained bursting may result in excessive calcium entry and cytotoxicity $[11,12,81-83]$. Excitotoxic injury in the hippocampus is associated with axonal sprouting and synaptic rearrangement [56, $57]$ and these processes may be regulated by EAA receptor activation [84]. Such synaptic rearrangements are likely to occur in TLE $[24,59-61]$. The increased binding to NMDA and glycine modulatory receptors in TLE may be related to an adaptive regulatory response to neuronal injury. In experimental paradigms, an increase in the ratio of NMDA receptors to PCP receptors is associated with an increase in susceptibility to neuronal damage from intracerebral injections of the excitotoxic glutamate analogue NMDA [49]. If this occurs in humans, it could contribute to the development of an epileptogenic focus over time. This could be an ongoing, cycling process involving neuronal injury and adaptive synaptic reorganization $[23,24,56-61]$.

This project was supported by the Epilepsy Foundation of America's John Hughlings Jackson Clinical Research Fellowship (to E. A. G.), which is supported by the Burroughs Wellcome Fund, and by National Institutes of Health grant NS 15655. John W. McDonald is a recipient of a Medical Scientist Training Program fellowship (5T32 6M07863-07).

We thank K. O'Mara for technical assistance.

\section{References}

1. Meldrum B. Convulsant drugs, anticonvulsants and GABAmediated neuronal inhibition. In: Krogsgaard-Larsen P, ScheelKruger J, Kofod H, eds. GABA-neurotransmitters. Copenhagen: Munksgaard, 1979:390-405

2. Roberts E. Epilepsy and antiepileptic drugs: a speculative synthesis. In: Glaser GH, Penry JK, Woodbury DH, eds. Antiepileptic drugs: mechanisms of action. New York: Raven, 1980: $667-713$

3. Haefely WE. GABA and the anticonvulsant action of benzodiazepine and barbiturates. Brain Res Bull 1980;5(suppl 2): $873-878$

4. Lloyd KG, Munari C, Bosi L, et al. Biochemical evidence for the alterations of GABA-mediated synaptic transmission in parhological brain tissue (stereo EEG or morphological definition) from epileptic patients. In: Morselli PL, Lloyd KG, Loscher W, et al, eds. Neurotransmitters, seizures and epilepsy. New York: Raven, 1981:325-338

5. Olsen RW. The GABA postsynaptic membrane receptorionophore complex: site of action of convulsant and anticonvulsant drugs. Mol Cell Biochem 1981;39:261-279

6. Olsen RW, Snowman AM, Lee R, et al. Role of the gammaaminobutyric acid receptor complex in seizure disorders. Ann Neurol 1984;16(suppl):\$90-\$97

7. Roberts E. GABA-related phenomena, models of nervous system function and seizures. Ann Neurol 1984;16(suppl):S77S89

8. Burnham WM. The GABA hypothesis of kindling: recent assay studies. Neurosci Biobehav Rev 1989;13:281-288

9. Sloviter RS. On the role of seizure activity and endogenous excitatory amino acids in mediating seizure-associated hippocampal damage. In: Schwarcz R, Ben-Ari Y, eds. Excitatory amino acids and epilepsy. New York: Plenum, 1985:659-671

10. Bradford HF, Dodd PR. Biochemistry and basic mechanisms of epilepsy. In: Davison AN, ed. Biochemistry and neurological disease. Oxford: Blackwell, 1976:114-167

11. Olney JW. Excitatory transmitters and epilepsy-related brain damage. Int Rev Neurobiol 1985;27:337-362

12. Meldrum BS, Simon RP, Swan J, et al. Calcium loading of mitochondria in ischemia and status epilepticus: its reversibility and significance for pathological outcome. In: Godfrain $T$, Vanhoutte PM, Govoni S, et al, eds. Calcium entry blockers and tissue protection. New York: Raven, 1985:183-194 
13. Meldrum B. Possible therapeutic applications of antagonists of excitatory amino acid neurotransmitters. Clin Sci 1985;68: $113-122$

14. Cotman CW, Monaghan DR, Otterson OP, Storm-Mathisen J. Anatomical organization of excitatory amino acid receptors and their pathways. Trends Neurosci 1987;10:273-280

15. Olney JW, Ho OL, Rhee V. Cytotoxic effects of acidic and sulphur containing amino acids on the infant mouse central nervous system. Exp Brain Res 1971;14:61-78

16. Shinozaki $\mathrm{H}$. Pharmacology of the glutamate receptor. Prog Neurobiol 1987;30:399-435

17. Nadler JV, Perry BW, Cotman CW. Intraventricular kainic acid preferentially destroys hippocampal pyramidal cells. Nature 1978;271:676-677

18. Olney JW, Fuller T, Degubareff T. Acute dendrotoxic changes in the hippocampus of kainate treated rats. Brain Res 1979; 176:91-100

19. Sloviter RS. "Epileptic" brain damage in rats induced by sustained electrical stimulation of the perforant path. I. Acute electrophysiological and light microscopic studies. Brain Res Bull 1983;10:675-697

20. Olney JW, De Gubareff T, Sloviter RS. "Epileptic" brain damage in rats induced by sustained electrical stimulation of the perforant path. II. Ultrastructural analysis of acute hippocampal pathology. Brain Res Bull 1983;10;699-712

21. Sloviter RS, Dempster DW. "Epileptic" brain damage is replicated qualitatively in the rat hippocampus by central injection of glutamate or aspartate but not by $\mathrm{GABA}$ or acetylcholine. Brain Res Bull 1985;15:39-60

22. Margerison JH, Corsellis JAN. Epilepsy and the temporal lobes. A clinical, electroencephalographic and neuropathological study of the brain in epilepsy, with particular reference to the temporal lobes. Brain 1966;89:499-530

23. Meldrum BS, Corsellis JAN. Epilepsy. In: Adams JH, Corsellis JAN, Duchen LW, eds. Greenfield's neuropathology. New York: Wiley, 1984:921-950

24. Scheibel ME, Crandall PH, Scheibel AB. The hippocampaldentate complex in temporal lobe epilepsy. Epilepsia 1974;14: $55-80$

25. Dam AM. Hippocampal neuron loss in epilepsy and after experimental seizures. Acta Neurol Scand 1982;66:601-642

26. Croucher MJ, Collins JF, Meldrum BS. Anticonvulsant action of excitatory amino acid antagonists. Science 1982;216:899-901

27. Czuczwar SJ, Meldrum B. Protection against chemically induced seizures by 2-amino-7-phosphonoheptanoic acid. EurJ Pharmacol 1982;83:335-338

28. Labuyere J, Fuller TA, Olney JW, et al. Phencyclidine and ketamine protect against kainic acid-induced seizure related damage. Soc Neurosci Abstr 1986;12:344

29. Callaghan DA, Schwark WS. Pharmacological modification of amygdaloid-kindled seizures. Neuropharmacology 1980;19: 1131-1136

30. Bowyer JF. Phencyclidine inhibition of the rate of kindling development. Exp Neurol 1982;75:172-183

31. Sato K, Morimoto K, Okamoto M. Anticonvulsant action of a non-competitive antagonist of NMDA receptors (MK-801) in the kindling model of epilepsy. Brain Res 1988;463:12-20

32. MeNamara JO, Russell RD, Rigsbee L, Bonhaus DW. Anticonvulsant and antiepileptogenic actions of MK-801 in the kindling and electroshock models. Neuropharmacology 1988;22:562568

33. Gilbert ME. The NMDA-receptor antagonist, MK-801, suppresses limbic kindling and kindled seizures. Brain Res 1988; 462:90-99

34. Van Gelder NM, Sherwin AL, Rasmussen T. Amino acid content of epileptogenic human brain: focal versus surrounding regions. Brain Res 1972;40:385-393
35. Avoli M, Olivier A. Bursting in human epileptogenic neocortex is depressed by an $\mathrm{N}$-methyl-D-aspartate antagonist. Neurosci Lett 1987;76:249-254

36. Sherwin A, Robitaille Y, Quesney F, et al. Excitatory amino acids are elevated in human epileptic cerebral cortex. Neurology 1988;28:920-923

37. Engelsen B. Neurotransmitter glutamate: its clinical importance. Acta Neurol Scand 1986;74:337-355

38. Cotman CW, Iversen LL. Excitatory amino acids in the brainfocus on NMDA receptors. Trends Neurosci 1987;10:283285

39. Olsen RW. GABA-benzodiazepine-barbiturate receptor interactions. J Neurochem 1981;37:1-13

40. Greenamyre JT, Olson JMM, Penney JB, Young AB. Autoradiographic characterization of $\mathrm{N}$-methyl-D-aspartate, quisqualate- and kainate-sensitive glutamate binding sites. J Pharmacol Exp Ther 1985;233:254-263

41. Maragos WF, Penney JB, Young AB. Anatomic correlation of NMDA and ${ }^{3} \mathrm{H}-\mathrm{TCP}$-labeled receptors in rat brain. J Neurosci 1988;3:493-501

42. McDonald JW, Penney JB, Johnston MV, Young AB. Characterization and regional clistribution of strychnine-insensitive $\left[{ }^{3} \mathrm{H}\right]$ glycine binding sites in rat brain by quantitative receptor autoradiography. Neuroscience 1990;35:653-668

43. Chu DCM, Maragos WF, Penney JB, Young AB. Magnesium ions increase binding affinity of dissociative anesthetic receptors but not of NMDA receptors in rat brain. In: Cavalheiro EA, Lehmann J, Turski L, eds. Frontiers in excitatory amino acid research, neurology and neurobiology, vol 46. New York: Alan Liss, 1987:567-570

44. Cha JJ, Greenamyre J, Nielson EO, et al. Properties of quisqualate sensitive $\mathrm{L}-\left[{ }^{3} \mathrm{H}\right]$ glutamate binding sites in rat brain as determined by quantitative autoradiography. J Neurochem 1988; 51:469-478

45. Pan HS, Frey KA, Young AB, Penney JB. Changes in $\left[{ }^{3} \mathrm{H}\right]$ muscimol binding in substantia nigra, endopeduncular nucleus, globus pallidus and thalamus after striatal lesions as demonstrated by quantitative receptor autoradiography. J Neurosci 1983;3: $1189-1198$

46. Penney JB, Young AB. Quantitative autoradiography of neurotransmitter receptors in Huntington's disease. Neurology 1982;32:1391-1395

47. Walker FO, Young AB, Penney JB, et al. Benzodiazepine receptors in early Huntington's disease. Neurology 1984;34: $1237-1240$

48. Hosford DA, Crain BJ, Bonhaus DW, et al. Radiohistochemical demonstration of altered quisqualate and N-methyl-D-aspartate receptor/channel binding in epileptic human hippocampi. Epilepsia 1989;30(5):719

49. McDonald JW, Silverstein FS, Johnston MV. MK-801 pretreatment enhances NMDA-mediated brain injury and increases brain NMDA recognition site binding in rats. Neuroscience 1990;38:103-113

50. Yeh G-C, Bonhaus DW, Nadler JV, McNamara JO. N-methyl$\mathrm{D}$-aspartate receptor plasticity in kindling; quantitative and qualitative alterations in the $\mathrm{N}$-methyl-D-aspartate receptor-channel complex. Proc Natl Acad Sci USA 1989;86:8157-8160

51. Young AB, Greenamyre JT, Hollingsworth Z, et al. NMDA receptor losses in putamen from patients with Huntington's disease. Science 1988;241:981-983

52. Kemp JA, Foster AC, Wong EHF. Non-competitive antagonists of excitatory amino acid receptors. Trends Neurosci 1987;10: $294-298$

53. Greenamyre JT, Penney JB, D'Amato CJ, Young AB. Dementia of the Alzheimer's type; changes in hippocampal L- $\left[{ }^{3} \mathrm{H}\right]$ glutamate binding. J Neurochem 1987;48:543-551

54. Geddes JW, Chang-Chui H, Cooper SM, et al. Density and 
distribution of NMDA receptors in the human hippocampus in Alzheimer's disease. Brain Res 1986;399:156-161

55. Geddes JW, Cooper SM, Cotman CW, Patel S. N-methyl-Daspartate receptors in the cortex and hippocampus of baboon. Neuroscience 1989;32:39-47

56. Nadler JV, Perry BE, Cotman CW. Selective reinnervation of hippocampal area $\mathrm{CA} 1$ and fascia dentata after destruction of CA3-CA4 afferents with kainic acid. Brain Res 1980;182: $1-9$

57. Tauck DL, Nadler JV. Evidence of functional mossy fiber sprouting in hippocampal formation of kainic acid treated rats. J Neurotox 1985;5:1016-1022

58. Sutula T, Xiao-Xian H, Cavazos J, Scott G. Synaptic reorganization in the hippocampus induced by abnormal functional activity. Science 1988;239:1147-1150

59. De Lorenzo RJ, Glaser GH. Neuropathologic changes and neuronal plasticity in temporal lobe-limbic epilepsy. Neurology 1981;31:114

60. De Lorenzo RJ, Glaser GH, DeLucia P, Schwartz D. The role of neuronal plasticity in epilepsy. Neurology 1982;32: A92

61. de Lanerolle NC, Kim JH, Robbins RJ, Spencer DD. Hippocampal interneuron loss and plasticity in human temporal lobe epilepsy. Brain Res 1989;495:387-395

62. McDonald JW, Johnston MV. Physiological and parhophysiological roles of excitatory amino acids during central nervous system development. Brain Res Rev 1990;15:41-70

63. Wyler AR, Nadi NS, Porter RJ. Acetylcholine, GABA, benzodiazepine and glutamate receptors in the temporal lobe of epileptic patients. Neurology 1987;31(suppl 1):103

64. Geddes JW, Cahan LD, Cooper SM, et al. Altered distribution of excitatory amino acid receptors in temporal lobe epilepsy. Exp Neurol 1990;108:214-220

65. Jansen KLR, Faull RLM, Dragunow M. Excitatory amino acid receptors in the human cerebral cortex: a quantitative autoradiographic study comparing the distributions of $\left[{ }^{3} \mathrm{H}\right] \mathrm{TCP}$, $\left[{ }^{3} \mathrm{H}\right]$ glycine, L- $\left[{ }^{3} \mathrm{H}\right]$ glutamate, $\left[{ }^{3} \mathrm{H}\right] A M P A$ and $\left[{ }^{3} \mathrm{H}\right]$ kainic acid binding sites. Neuroscience 1989;32:587-607

66. Maragos WF, Chu DCM, Young AB, et al. Loss of hippocampal $\left[{ }^{3} \mathrm{H}\right] \mathrm{TCP}$ binding in Alzheimer's disease. Neurosci Lett 1987; 74:371-376

67. Johnson M, Perry RH, Chariton FG, et al. Distribution of $\left[{ }^{3} \mathrm{H}\right] \mathrm{MK}-801$ binding in the normal aged human hippocampus. Brain Res 1989;499:184-187

68. Yi S-J, Snell LD, Johnson KM. Linkage between phencyclidine (PCP) and N-methyl-D-aspartate (NMDA) receptors in the cerebellum. Brain Res 1988;445:147-151

69. Loo P, Braunwalder A, Lehmann J, Williams M. Radioligand binding to central phencyclidine recognition sites is dependent on excitatory amino acid receptor agonists. Eur J Pharmacol $1986 ; 123: 467-468$

70. Snell LC, Morter RS, Johnson KM. Glycine potentiates Nmethyl-D-aspartate induced $\left[{ }^{3} \mathrm{H}\right] \mathrm{TCP}$ binding in rat cortical membranes. Neurosci Lett 1987;83:313-317

71. Procter AW, Stirling JM, Stratmann GC, et al. Loss of glycinedependent radioligand binding to the $\mathrm{N}$-methyl-D-aspartatephencyclidine receptor complex in parients with Alzheimer's disease. Neurosci Lett 1989;100:62-66

72. Proctor AW, Wong EHF, Stratmann GC, et al. Reduced glycine stimulation of $\left[{ }^{3} \mathrm{H}\right] \mathrm{MK}-801$ binding in Alzheimer's disease. J Neurochem 1989;53:698-704

73. Steele JE, Palmer AM, Stratmann GC, Bowen DM. The Nmethyl-D-aspartate receptor complex in Alzheimer's disease: reduced regulation by glycine but not zinc. Brain Res 1989; 500:369-373

74. Babb TL, Brown WJ, Pretorius J, et al. Temporal lobe volumetric cell densities in temporal lobe epilepsy. Epilepsia 1984;25: $729-740$

75. Falconer MA, Serafetinides EA, Corsellis JAN. Etiology and pathogenesis of temporal lobe epilepsy. Arch Neurol 1964;10: 233-248

76. Sherwin A, Matthew E, Blain M, Guevrement D. Benzodiazepine receptor binding is not altered in human epileptogenic cortical foci. Neurology 1986;36:1380-1382

77. Herron CE, Williamson R, Collingridge GL. A selective Nmethyl-D-aspartate antagonist depresses epileptiform activity in rat hippocampal slices. Neurosci Lett 1985;61:255--260

78. Herron CE, Lester RAJ, Coan EJ, et al. Intracellular demonstration of an N-methyl-D-aspartate receptor mediated component of synaptic transmission in rat hippocampus. Neurosci Lett 1985;60:19-23

79. Dingledine R. NMDA receptors: what do they do? Trends Neurosci 1986;9:47-49

80. Hablitz JJ, Langmoen IA. N-methyl-D-aspartate receptor antagonists reduce synaptic excitation in the hippocampus. J Neurosci 1986;6:102-106

81. Heinemann U, Lux HD, Gutnick MJ. In: Chalazonitis N, Boisson M, eds. Abnormal neuronal discharges. New York: Raven, 1978:329-395

82. Meldrum BS. Metabolic effects of prolonged epileptic seizures and their relation to nerve cell death. In: Ross FC, ed. Metabolic disorders of the nervous system. London: Pitman, 1981:178187

83. Clifford DB, Zorumski CF, Olney JW. Ketamine and MK-801 prevent degeneration of thalamic neurons induced by focal cortical seizures. Exp Neurol 1989;105:272-279

84. Mattson MP. Neurotransmitters in the regulation of neuronal cytoarchitecture. Brain Res Rev 1988;13:179-212 